\title{
AN OVERVIEW OF THE STUDY OF TREPANATION IN THE TERRITORY OF SERBIA
}

\begin{abstract}
Trepanations are the oldest known type of surgical intervention on the head of man. The reasons for which they were done were different. These were therapeutic tranches as well as those that were performed for magical purposes.

From the area of our country of trepanation, they come from just a few sites from the Iron Age, through the Roman period, to the Middle Ages. The instruments and techniques that were used for trepanning are differed in different periods. On the other hand, the trepanations did not cease to be practiced even in the younger periods when it comes to the area of our country. They are practiced in these areas even at the time when modern medicine is developing and expanding, which is a unique case in Europe. There is a lot of ignorance about the process of trepanning when it comes to older periods, how it happened and what it all meant. For the period of the 19th and 20th centuries, these data are more precise and they speak about the great representation of this element of health care in Serbia, Montenegro and Albania and possibly they can help to explain the process of trepanning in the previous periods.

In this paper an attempt was made to present all the tranches from these spaces, including all the periods in which they were carried out. Another important segment is to make an attempt to reconstruct as well as to clarify the flow of trepanning in a more precise manner.
\end{abstract}

KEYWORDS: TREPANATIONS, INSTRUMENTS, SKULLS, TECHNIQUES, SURGICAL INTERVENTION, MEDICAL PROCESS, HISTORICAL PERIODS.

\section{INTRODUCTION}

From the aspect of medical history, archaeology and anthropology, trepanation is the oldest surgical intervention on the human head. This technique involves breaking the skullcap with a special instrument and an intervention on the meninges (Dura mater). ${ }^{1}$ For several millennia, until the modern era, skull trepanation was performed by

1 The article is the result of the project: Viminacium, Roman city and military camp - research of material and non- material culture of inhabitants by using the modern technologies of remote detection, geophysics, GIS, digitalization and $3 D$ visualization (no 47018), funded by The Ministry of Education, Science and Technological Development of the Republic of Serbia. individuals whose work remained for us to study.

The reasons for trepanation were varied, especially in prehistoric times. They included persistent headaches, various injuries, but also psycho-suggestive magic, i.e. exorcism (banishment) of evil spirits from the body. In time, as demonstrated by the case with the Serbian population, trepanation was performed only as a result of head injuries in combat or in various falls. In Serbia, this technique was successfully practiced throughout the $19^{\text {th }}$ century. It was performed by the socalled folk healers, whose names we managed to obtain, as well as the names of the people who were trepanned several times during their life. 
The aim of this paper is to investigate this field of health care among the Serbs in the 19th century, since the practice of trepanation performed by folk healers was retained the longest in Europe. We believe that the reasons for that were the socio-historical circumstances at the time, as will be more thoroughly discussed later in this paper. The second objective of this work is to attempt to unravel the process of trepanation, because it represents an unknown when it comes to earlier periods of time.

\section{HISTORY OF RESEARCH}

The phenomenon of trepanation is a very complex and demanding topic. For this reason, we will give a brief overview of the findings regarding trepanned skulls in Europe, as well as those from the territory of Serbia.

According to G. Buschan (1937), the oldest trepanations were performed about ten thousand years ago (sites in Dordogne, France). This means that they were performed with some kind of instruments that predated the discovery of metal, which means that only stone tools could have been used (for example silex). Such stone knives have not been found near trepanned skulls, but their existence must be presumed, because they were not post-mortem (but ante-mortem) trepanations.

When it comes to a somewhat later period, for example, the Neolithic in Germany, H. Ulrich and F. Weickmann (1964) found a skull without the skull dome, which was definitely taken off with a stone instrument. However, the preserved metal instrument published by J. Como (1925) was found at the Rhine Limes at Bingen. This is already a historic period, but prehistoric metal instruments which could be reliably linked to skull trepanation in Europe have not yet been found.

Trepanned skulls from historic periods of Europe are numerous. So far, several thousand have been recovered, and their number varies from country to country and from period to period
(Hein, P. 1960). So, for example, in neighbouring Hungary, skulls have been recovered from over 50 sites (Nemeskeri, J. 1960).

In Serbia, the oldest trepanned skulls come from the Bronze Age necropolis at Mokrin (Northern Banat). Hungarian anthropologists Farkas, G. and Lipták, P. (1971) published papers dealing with a total of 9 of these specific skulls. The site of Kriva Reka (Western Serbia) yielded one skull from the Iron Age, but it was trepanned three times during the life of that individual (Schulz 1993). From the historical period, we have trepanned skulls from the Antique Viminacium, from the medieval necropolis at Gamzigrad (Felix Romuliana) and from the necropolis of the monastery of Davidovica near Prijepolje (Mikić 1998).

The study of the phenomenon of trepanation in Europe is linked to 1873, when Prunieres showed, at a congress in Lyon, one skull found in 1868 (Prunieres, P. 1873). Further information about trepanation was obtained in 1876 at the International Congress of Anthropology and Archaeology, in Budapest. It was then that the French anthropologist P. Broca (1877) introduced the differentiation of "trepanation posthume" and "trepanation chirurgicala". He also posed the problem of survival after this complicated neurosurgical intervention, which is still valid in the study of trepanation today. In the 20th century, the number of studies increased so much that they exceed the limits of this paper. Let us mention, among other things, that D. R. Brothwell (1981) wrote a significant monograph on trepanation from the aspect of ethno-medicine. It should be noted that the abovementioned author listed several types of trepanation: circular, rectangular and the case when the drilled holes form a circle. When it comes to positions where trepanation was performed, the frontal, parietal and temporal regions are the most common.

For now, the only well preserved instruments used for trepanation from the Roman period come from the site of Bingen upon Rhine (Como 1925, in: Mikić, 2007, p. 1). The tool, the so-called tre- 
pan, was a very precise instrument for that time, which maintained the direction of the drilling of the skull.

Another important find is an improved form of instrument for trepanation that comes from an Avaric grave in Hungary (Mezóband). It functioned on the principle of a bow and arrow, where the trepan stood vertically and entered the positioned horizontally bow and, thus, the process of trepanation was faster (Anda 1951, in Mikić, 2007, p. 2).

The very term of trepanation comes from Greek and French, and belongs to newer ethno-medicine, meaning, in short, the piercing of the head (Pahl, 1993).

The first pieces of information about trepanation among the Serbs in the 19th century and, therefore, the beginning of the research, were found in Berlin, where a trained physician, Dr. Vladimir Đorđević (1883), in the context of his article on health care in the Kingdom of Serbia, mentioned trepanation very briefly. Then, the first educated anthropologist from Serbia, Sima Trojanović, also in Germany, in 1900, published an extensive article on trepanation among the Serbs (Trojanović 1900), which he expanded and published in Serbian in Skopje (Trojanović 1922).

It is very interesting to note that, particularly in the second half of the 20th century, the research of trepanation on the recent population does not continue, on the contrary, the focus is on skeletal findings from prehistoric and historic periods. This fact is certainly in contradiction with the fact that trepanation was practiced in the 19th century.

\section{MATERIAL AND METHOD}

Considering the fact that one of the aims of this research is tracking a segment of folk medicine among Serbs in the 19th century, the basic material available to us is the corresponding literature of an earlier date, in particular, M. Iličković, from 1940, and M. Brajković, from 1948. By gaining insight into these articles, we can see that they exclusively quote the relative foreign literature, from which we can conclude that they were the pioneers who began to study the phenomenon of trepanation among the Serbs in the 19th century.

We do not have more recent research papers that would delve further into trepanation as a segment of the history of folk medicine, i.e. the health care of the people. It can be concluded from this that, in the second half of the 20th century, this topic was, some reason, ceased to be studied, regardless of the fact that this practice continued until the very beginning of the 20th century. On the other hand, we have published works on trepanation on skeletal material, but they are not directly related to this article.

The method applied in this paper is primarily analytic (Šamić 1988) - interpretative, with the goal of pointing out the designation of special categories such as: folk healers, medicines, patients, instruments, service price and origins of trepanation.

\section{RESULTS}

Folk healers, self-taught doctors, were called "medig" or simply doctors. The most famous folk healers known for performing trepanations were from the Iličković family from Crmnička Nahija, who, according to sources, trepanned between 200250 people. Among them, the most prominent were Niko Mićov, and his father and uncle, Pero and Miko. Radovan Bulić from Drobnjaci, Radosav Radičević from Vasojevići and Radosav Petrović from Kuči (died in 1928) were also mentioned.

Aside from the self-taught folk healers, there were, for example, in Montenegro in the 1880s, two "educated" doctors: one captured Greek and one "Turkish Jew".

At the end of the 19th century, in Cetinje, the head of the Medical Service was Dr. Niko Miljanić, educated in Germany. Sima Trojanović used his notes on the trepanation process in his works published in 1900 and 1922.

The patients were "peasants with injured 
heads, who usually suffer for 40 days, and if the pain, which often renders them blind, doesn't go away, and they do not expect that they will be able to recover by self-healing, they are subjected to trepanning”. Sima Trojanović didn't find any information about the trepanning of individuals with mental health problems.

When it comes to the trepanning of "patients", from a certainly considerable number of names the following list remained: Bajo Karadžić (from Drobnjaci) seriously injured his head in a quarrel. After the procedure he was completely healed.

Radovan Juričić from Vasojevići was trepanned at the age of 55 because of a heavy blow to the head. Then he felt well for the rest of his life.

Veljko Babović from Dulipolja village (the municipality of Konjuška in Montenegro) was successfully trepanned at the age of 84 . He lived without any consequences until he passed away in 1878. The first time he "underwent the procedure he was in his middle age".

Jakov Gorašev from Oždmidrjien (a village in Bjelopavlići) had his upper skull crushed. He underwent the procedure and after being "mended" he lived for another 15 years. He died of another illness and was buried at the church in Frutak.

Next we have Borika Savina, born in Morača and trepanned in Dakiši village in Vasojevići. After that, she lived normally without feeling any pain. Nikola Spahov Ručić from Kuči had his head trepanned at a younger age, and died in 1930 at the age of 80 (Barjaktarović 1948, p. 555).

It needs to be pointed out that Sima Trojanović (Trojanović, 1922, p. 4) noted that he deliberately mentioned the burial places of individuals who underwent the procedure of trepanation, "so that their skulls would be transferred to a museum, at a convenient moment, as significant scientific objects". His attempts with fine words and money failed, because people were convinced that it would be a desecration of the deceased. However, on this occasion, his sense of the importance of scientific proof should be emphasised, with the remark that he was the first educated Serbian anthropologist, who received his Ph.D. from the University of Heidelberg.

The basic instrument for this neurosurgical intervention of folk healers, as already mentioned, was called the šara or trapanj, depending on the local dialect. It was actually a tube serrated on one side only to scrape (šaronjati) the cranial bone. It used to be made by rural blacksmiths, from a barrel of a pistol or a rifle. The length was ca 12-15 $\mathrm{cm}$, and good medics had several of them with different diameters (to use them as needed).

Razors or blades for removing hair and cutting skin are certainly more standard instruments, but they were also necessary for every trepanation.

To clean the skull from soft tissues beneath the skin, there was a special knife called the lešper. It certainly had to have been some type of scraper (skinner). There were also usually three kukača (hooked instruments). One was used by the medig and the other two by his assistant. These tools were used so that at one point, on a given command, all 3 would be activated in the same way and, thus, raise the bone disc from the skull (which was previously processed with the šara instrument).

A silver spoon was used to collect clotted blood (to remove a hematoma) from the outer meningeal layer. Silk cotton could have been used for the same purpose.

The trepanation instruments were seven in total and comprised: šara or trepanj, various knives and blades, lešper, hooks, chisel, sewing needle and spoon. Their total number did not have to be the same for every folk healer, and it probably varied depending on how well equipped one was.

Instruments belonging to the folk healers of the Iličković family have been kept in a complete archive at the Surgical Clinics Museum of the Faculty of Medicine in Moscow since 1907 (Iličković, 1940).

Medications should be divided into two groups. The first would include those that had the role of opiates (certain types of anaesthesia), and in the second group would be the preventive, or protective medications. 
The second group of medications would include unctions. One was used when the medig didn't want to use the appropriate knife to remove soft tissues above the bone (below the skin). Then he would leave the job to a herbal unction to "bite to the bone". The name of this unction remains unknown.

Another unction had a different usage. It was used after the procedure and was called boletin. It was used on the wound after restoring and stitching the skin. Its' composition is not completely known and Sima Trojanović (Trojanović, 1922, p. 2) said that he didn't manage to find out all the herbs that were used to make it, but that he knew "they tend to add some wax and "čansa", and then leave it all to rest in oil". Boletin would usually remain on the wound for four to five weeks.

It is also interesting to mention the use of the calabash. Its' bark would be cut and shaped and then placed above the trepanned spot when the opening on the skull was large, but it wasn't allowed to come in contact with the meningeal layer (Dura mater).

For such cases it is possible to assume that the folk healers probably knew of some antiseptic and antibiotic effects of the mentioned gourd or pumpkin, and that it was not merely a mechanical protection during the process of bone healing (osteoplastic reaction). Brandy was used as an anaesthetic, 1 litre for men and 3/4 litre for women.

Trepanation could be one of several prices. Basically, medigs were paid by arrangement. In cases when the patient was wounded by a "nekrst" (Non-Christian or Muslim, Turk), the procedure was free. However, if he was wounded by a Serb, then the Senate (Great Court or Kuluk) in Montenegro determined that a penalty fine be paid. In addition, the attacker had to pay some compensation to the injured, for the pain sustained. In Andrijevica, "full blood" was 336 thalers and 6 groschen, and in Zeta this fine was 133 thalers and 2 groschen. This penalty was called Berberina or Berberija.

In cases when the injured individual died during the trepanation, the killer was obliged "to pay for the blood with his own head or a head of his family, or the so-called settlement" which was called "to settle a šara with a šara". This system was legally sanctioned later, but we were unable to find the precise time when that happened from the data available, except that it is mentioned that in 1856 Prince (vladika) Danilo banned trepanation performed by folk healers. They fled to southern Serbia and Albania at that time.

For cases when the patient died during trepanation, S. Trojanović (Trojanović, 1922, p. 4) quotes the note given to him by J. Cvijić. It refers to Arnauts, whose folk healers also practiced trepanation, and it states that the "ećim" (folk physician) was trepanning prominent Arnauts under blood warranty. If a patient died "under the knife", the ecim was to pay with his own head. Sometimes, it was, of course, possible to compensate for the lost life with money (Trojanović, 1922, p. 5). The sum that would normally be paid in such cases is not stated.

Forgiveness of blood was also mentioned - the folk healers would ask for it before the "surgery" to secure themselves. The Grbljan Code of Arbitration (Article 103) clearly states: "So that the wounded would not leave a blood debt on a doctor, who is to cut his wound or heal his head, we allow for the doctor who would do the procedure to give his hand to the injured, who would thus testify that doctor's life is his own even if he, the patient, should die" (Vrčević, 1891, p. 40; Barjaktarović, 1948, p. 556).

\section{The process of trepanation}

Since we have already identified, systematised and analysed the most important categories, such as folk healers, patients, doctors, instruments, medications and prices, we can now turn our focus to the process of trepanation itself. The medig did not work on his patients alone, but with the help of an assistant. The assistant would hold the patient, who sat on a chair, with hands over the ears and fingers on the temples, tightly. It is assumed that anaesthetic was taken first of all (in our case the 
above mentioned amount of brandy, perhaps even taken in one shot). Once the hair was removed from the right place with a specific instrument, the skin was open with a cross-cut and soft tissue removed from the designated spot; then the process of trepanation would begin. The folk healer would put more pressure on the wound towards himself, which would make it possible for him to get closer to the outer meningeal layer. Once this was done, he would take the hooks (and/or the chisel) and, together with his assistant, working in unison, raise the bone disc. Then the blood from internal haemorrhaging would be collected (hematoma) and/or tiny bone pieces in cases of larger injuries. When all that was done, the raised piece of skin would be lowered down and sewn with the appropriate needle. This would be followed by placing the balm (Boletin), though the skin would not be completely sewn. Folk healers thought that "air access" was needed so that the wound would heal faster.

When the entire surgical part of the procedure was completed, the wound would be bandaged with a kušak, which certainly had a compressive protective role as well. It was considered that the wound in strong young men would be healed in 14 days, in the elderly in 40 days, and weaker people would heal in 2 months. It was also said that if the trepanned opening was big, then the skin at the wound area would swell (pulse), while the bone healed.

From this data we can see that the osteoplastic bone reaction was a known occurrence in the human organism.

After this complicated neurosurgical intervention, the patient would not be allowed to do heavy physical work.

It should be added that in relation to the coalescence of the trepanned opening Barjaktarović (Barjaktarović, 1948, p. 555) mentions the "skulls of the dug-out deceased", but does not list them. The data cannot be taken as reliable, so we should rely on a single case presented by Trojanović (Trojanović, 1900, p. 20). It is said that during the exhumation of the grave of a man, who had his skull trepanned three times in the period of ten years, it could be seen how the openings on the trepanned skull gradually healed. On the same occasion, it is said that very few people died during trepanation. However, we do not have reliable data on mortality rates, so this is among the questions that remain open.

\section{Origin}

As can be seen from the available literature as the only source of data, the origin of the trepanation can be viewed in two ways. For example, the word šara is of purely Arnauts origin, and trapanj (trapanjanje or trapovanje) is a local modification of the ancient Greek word trepanon/tripanon. The term trepanation was adopted in modern science.

It is most probable that this medical experience began to spread from ancient Greece towards the north in the period of transition from prehistory to the historical period, so that in the 19th century it was still practiced only by the Serbs and Arnauts. We should also mention the Vlachs here, who practiced trepanation in the village of Zlot, in 1907 (Trojanović, 1922, p. 5).

\section{Open questions}

After the "scanning" of the phenomenon of the trepanation that we tried to carry out, a phenomenon that lasted for several millennia in Europe - and one that is practiced even today in modern neurosurgery - there are certainly a lot of questions left open. When it comes to the practice and experiences of the Serbs in the 19th century, some of them must be pointed out.

The question of the assistant is one of the first. We could not determine whether it was a permanent assistant who followed the folk healer and learnt on his way, or if it was just a person who happened to be nearby and who helped during the trepanation.

Bone plugs are mentioned, which are removed, by using kukače (and chisels), by a simultaneous action of the doctor and the assistant. However, nothing is said about what happened to them after 
the trepanation. Were they destroyed or kept? In prehistoric times, they were used as amulets. The question is whether this can be viewed as an analogous phenomenon?

A needle for sewing the wound is also mentioned, but nothing about the thread that was used. It would be interesting to know which material was used for this purpose.

This list of open questions could be continued, because it simply increases with the increase of our interest in this medical phenomenon that was part of the folk medicine but is still present in modern neurosurgery.

An attempt to present the process of trepanation during the 19th century in the territory of Serbia is also an attempt to reconstruct the process of trepanation in the older periods, given the very long history of research this surgical procedure has. It can be assumed that the procedure itself did not change much with time, considering the instruments that were used depending on the technique of trepanation itself. The only difference is in the fact that, in the territory of Serbia, Montenegro and Dalmatia, a skull drilling technique was used, while in earlier periods it was a scalping / scraping technique. On this occasion, we should mention cases of trepanation from Viminacium where, out of a total of 14,000 excavated graves, of which $1 / 3$ were cremations, only three skulls with trepanation were found. These are a skull from the necropolis of Više Grobalja, skull G-1037, then from the necropolis of Pećine, skull G-2570, and from the site of Pirivoj, skull G-130, which was found and processed by the author of this article. The trepanations were carried out using the scraping technique, which represents a more primitive trepanning technique. The osteoplastic reaction is visible, indicating that the deceased lived long after surgery. Since it can be said, at the current level of research, that medicine in Viminacium was developed, the question arises as to why an older trepanation method was used. One of the more acceptable answers is that these people underwent the trepanation procedure somewhere else and that they came to Viminacium afterwards (Mikić, 2007).

On the other hand, another trepanned skull was found in medieval Gamzigrad, which had completely healed from the inside. Again, the scraping technique was used in this case, which means that this primitive technique was still in use during medieval times (Mikić, 2007).

Another observation that must be taken into account is the fact that in the territory of Serbia trepanation procedures were conducted mainly for the purpose of solving health problems (headaches and injuries), while in much earlier periods this practice had a role in magical rituals (symbolic and post-mortem trepanations), when bone discs from the skull were used as amulets. In our surrounding areas, such trepanations can often be found in the territory of Bulgaria (Boev, 1956, p. 55).

The next observation would also refer to the diffusion of trepanations that can be found in locations from Africa, through South America to Europe.

\section{CONCLUSION}

As pointed out in the introduction, the aim of this paper was to investigate a segment of health care among the Serbs in the 19th century. This segment is trepanation, which is still a very demanding and complicated neurosurgical intervention.

The results obtained are related to folk healers, patients, instruments, medications, prices, the process of trepanation itself, its' origin among the Serbs, as well as some open questions, and they can be considered as authentic, because the main source of data was Dr Niko Miljanić, a doctor educated in Germany and the head of the Medical Service at Cetinje, and also a great connoisseur of folk medicine in the territory of eastern Herzegovina, Montenegro and southern Dalmatia.

It transpires that the so-called folk medicine was present for a significantly longer time in the contemporary population of that period, compared 
to scientific medicine. On the other hand, there are other overall social and historical circumstances (organisation of life and social enlightenment), because of which trepanation was practiced the longest among the Serbs and Montenegrins when compared with the rest of Europe.

The process of trepanation in the territories that were the subject of this paper was explained almost entirely by referencing sources that can be largely considered to be complete. On the other hand, during the Iron Age, the Roman period and the Middle Ages, which were also the subject of this paper, we only know that the trepanation technique was different, i.e. that a scraping technique was used, which represents a more primitive technique. Hence, we can conclude that trepanations which were carried out until the first half of the last century in our region were more sophisticated, and as a possible result of this there was a large number of surviving patients, although we have no written evidence on mortality rates. Also, there is the fact that cemeteries from the $19^{\text {th }}$ century have not yet been the subject of study, and therefore they are inaccessible for anthropological research.

Let us add that after this revision and analysis, the elements obtained will certainly be used for a more reliable reconstruction of trepanation in significantly older periods, and even further, in its' beginnings. In this regard, this was very informative material for a detailed analysis in terms of medical history.

$$
* * *
$$

Arheologija i prirodne nauke (Archaeology and Science) is an Open Access Journal. All articles can be downloaded free of charge and used in accordance with the licence Creative Commons - Attribution-NonCommercial-NoDerivs 3.0 Serbia (https://creativecommons.org/licenses/bync-nd/3.0/rs/.

Časopis Arheologija i prirodne nauke je dostupan u režimu otvorenog pristupa. Članci objavljeni u časopisu mogu se besplatno preuzeti sa sajta i koristiti u skladu sa licencom Creative Commons
- Autorstvo-Nekomercijalno-Bez prerada 3.0 Srbija (https://creativecommons.org/licenses/bync-nd/3.0/rs/.

\section{BIBLIOGRAPHY}

\author{
Барјактаровић, М. 1948 \\ О шароњању (трепанацији), у Црној Гори, \\ Стварање 11-12, Цетиње: 553-557. \\ (Barjaktarović, M. 1948 \\ O šaronjanju (trepanaciji), u Crnoj Gori, Stvaranje \\ 11-12, Cetinje: 553-557.)
}

\section{Боев, П. 1959}

Вырху историчекие трепанации, Булгарска Академия Науките, София.

(Boev, P. 1959

V'rhu istoričekie trepanacii, Bulgarska Akademiia Naukite, Sofiia.)

\section{Broca, P. 1987}

Cranes perfores, Bulletins de la Societe d'anthropologie de Paris, tome 9. II serie.

\section{Brothwell, D. R. 1981}

Digging up bones - The Excavation, Treatment and Study of Human Skeletal Remains, Natural History Museum, Oxford University Press: Oxford.

\section{Buschan, G. 1937}

Die Methoden der primitiven trepanation, Ciba Zeitschrift 37, Berlin: 1-8.

\section{Como, J. 1925}

Das Grab eines römischen Arztes in Bingen, Germania-Korespodenzblat der RGK, Heft 3, Berlin: 7-36.

\section{Đorđević, V. 1883}

Die Entwicklung der öffentlichen Gesundheits pflege im serbischen Köningsreiche vom XII jahrhundert an bis 1883, Berlin: 8. 
Farkas, Gy., P. Liptak 1971

Antropološka istraživanja nekropole u Mokrinu, Disertationes et Monographie XI, Arheološko društvo Jugoslavije, Beograd: 239-271.

\section{Iličković, M. 1940}

Prilog proučvanju istoriji narodne medicine kod Južnih Slovena, Biblioteka Centralnog higijenskog zavoda u Beogradu XI, Beograd.

\section{Mikić, Ž. 1998}

Über Trepanation im Gebiet von der Adria bis zum Schwartzen Meer-Ein, Anthropologischen Beitrag, Praehistorische Zeitschrift 73 band/heft 2, Berlin: 145-150.

\section{Mikić, Ž., 2007}

Vek istraživanja trepanacija u Srbiji, Antropološki pregled 4, Beograd.

Nemeskeri, J., E. Kinga, A. Kralovansky, 1960 A magyarorszagy jekepes trepanacio, Antropologiai Közlemenyek IV/1-2, Budapest, 3-32.

Pahl W. M. 1993

Altägiptische Schädelchirurgie, G. Fischer Verlag, Sttutgart-Jena-New York.

\section{Prunieres, P. 1873}

Ass. frc. avanc. d. sci. Lyon.

\section{Shulz, M. 1993}

Spuren unspezifischer Entzündungen an prähistorische und historischen Schädeln, Anthropologische Beitrage 4/a-b, Bassel-Aesch.

\section{Šamić, M. 1988}

Kako nastaje naučno djelo, Svjetlost Sarajevo.

\section{Trojanović, S. 1900}

Die Trepanation bei den Serben, Ein etnographischer Beitrag, Correspodenz-Blatt der deutschen Gesselschaft für Anthropologie, Ethnologie und Urgeschichte, XXXI/3, Berlin: 18-23.

\section{Тројановић, С. 1922}

Шароњање код Срба-нови подаци, Јужна Србија за 1922. годину, Скопље: 1-7.

\section{Ulrich, H., Weickman, F. 1964}

Prächistorische "Neurochirurgie" im mitteldeuche Raum, Centralblatt für Neurochirurgie 24, Berlin: 103-121.

Врчевић, В. 1891

Разни чланци, Дубровник: 40.

(Vrčević, V. 1891

Razni članci, Dubrovnik: 40.)

\section{REZIME \\ OSVRT NA PRUČAVANJA TREPANACIJA SA PODRUČJA SRBIJE}

\section{KLJUČNE REČI: TREPANATIONS, INSTRU- MENTS, SKULLS, TECHNIQUES, SURGICAL INTERVENTION, MEDICAL PROCESS, HISTO- RICAL PERIODS.}

Trepanacija lobanje predstavlja jedan od najstarijih hirurških zahvata koji su do sada poznati. Na teritoriji Srbije je konstatovana na svega nekoliko nalazišta. To su praistorijska nalazišta Kriva Reka i Mokrin. U rimskom periodu je na Viminacijumu zabeleženo nekoliko primeraka trepanacija. U srednjem veku se ova praksa nastavlja na srednjovekovnim nekropolama u Gamzigradu i manastiru Davidovica kod Prijepolja. Trepanacije iz tih perioda su bile sprovedene starijom tehnikom trepaniranja. Ipak, trepanacije su se u Srbiji zadržale do 20. veka pri čemu se koristila druga, nešto naprednija metoda. Instrumentarijum je samim tim brojao više instrumenata, a cilj ovog rada je bio da se u što većoj meri rekonstruiše sam proces trepanacija. S obzirom da su se one na području naše zemlje, Crne Gore i Albanije zadržale duže nego bilo gde u Evropi, svakako da je proučavanje ovog fenomena bilo značajno sa više aspekata. Odgovor na pitanje zašto je narodna me- 
dicina imala prednost u odnosu na naučnu medicinu treba tražiti u ukupnim društveno istorijskim okolnostima, organizaciji života i društvenoj prosvećenosti koje nisu bile povoljne. 